\title{
Free gathering and movement of evidence in criminal matters in the EU : Thinking beyond borders, striving for balance, in search of coherence
}

Citation for published version (APA):

Vermeulen, G. (2011). Free gathering and movement of evidence in criminal matters in the EU : Thinking beyond borders, striving for balance, in search of coherence. Maklu. https://doi.org/10.26481/spe.20111028gv

Document status and date:

Published: 28/10/2011

DOI:

10.26481/spe.20111028gv

Document Version:

Publisher's PDF, also known as Version of record

Please check the document version of this publication:

- A submitted manuscript is the version of the article upon submission and before peer-review. There can be important differences between the submitted version and the official published version of record.

People interested in the research are advised to contact the author for the final version of the publication, or visit the DOI to the publisher's website.

- The final author version and the galley proof are versions of the publication after peer review.

- The final published version features the final layout of the paper including the volume, issue and page numbers.

Link to publication

\footnotetext{
General rights rights.

- You may freely distribute the URL identifying the publication in the public portal. please follow below link for the End User Agreement:

www.umlib.nl/taverne-license

Take down policy

If you believe that this document breaches copyright please contact us at:

repository@maastrichtuniversity.nl

providing details and we will investigate your claim.
}

Copyright and moral rights for the publications made accessible in the public portal are retained by the authors and/or other copyright owners and it is a condition of accessing publications that users recognise and abide by the legal requirements associated with these

- Users may download and print one copy of any publication from the public portal for the purpose of private study or research.

- You may not further distribute the material or use it for any profit-making activity or commercial gain

If the publication is distributed under the terms of Article 25fa of the Dutch Copyright Act, indicated by the "Taverne" license above, 


\section{FREE GATHERING}

AND MOVEMENT OF

EVIDENCE IN CRIMINAL

MATTERS IN THE EU

Thinking beyond borders,

striving for balance,

in search of coherence

Gert Vermeulen 
Free gathering and movement of evidence in criminal matters in the $E U$

Thinking beyond borders, striving for balance,

in search of coherence 



\title{
Free gathering and movement of evidence in criminal matters in the EU
}

\author{
Thinking beyond borders, \\ striving for balance, \\ in search of coherence
}

\author{
Inaugural Lecture \\ Held in accepting the position of \\ Extraordinary Professor of 'Evidence Law'
}

Prof. Dr. Gert Vermeulen

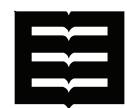

Maklu

Apeldoorn | Antwerp | Portland 


\section{Gert Vermeulen}

Free gathering and movement of evidence in criminal matters in the EU.

Thinking beyond borders, striving for balance, in search of coherence.

Antwerp | Apeldoorn | Portland

Maklu

2011

52 pag. $-24 \times 15,5 \mathrm{~cm}$

ISBN 978-90-466-0486-1

$\mathrm{D} / 2011 / 1997 / 76$

NUR 824

(C) 2011 Gert Vermeulen

All results reserved. No part of this publication may be reproduced, stored in a retrieval system, or transmitted in any form or by any means, electronic, mechanical, photocopying, recording, or other-wise without the prior permission of the author.

Maklu-Publishers

Somersstraat 13/15, 2018 Antwerp, Belgium, info@maklu.be Koninginnelaan 96, 7315 EB Apeldoorn, The Netherlands, info@maklu.nl www.maklu.eu

USA \& Canada

International Specialized Book Services

920 NE 58th Ave., Suite 300, Portland, OR 97213-3786, orders@isbs.com, www.isbs.com 


\section{Contents}

I. Free gathering of evidence 13

A. By whichever authorities, irrespective of the finality

of their actions?

1. A matter of judicial cooperation, by judicial authorities only?

2. Distinction judicial vs police cooperation: Artificial, often counterproductive or useless

3. Limited necessity for 'judicial' safeguards 20

B. Decisive marker: Criminal justice finality 22

1. Part of the EU acquis 22

2. Lack of finality demarcation problematic 23

3. Flexible finality demarcation? 28

C. Irrespective of the offence (definition) concerned? 31

D. Any investigative measure? 32

E. For free? 33

1. Financial capacity 34

2. Operational capacity 37

F. Without borders? 38

II. Free movement of evidence 41

A. Mutual admissibility of evidence gathered following a cooperation request $\quad 41$

1. Forum regit actum 41

2. Conceptual flaws and weaknesses of forum regit actum 42

3. Quick wins 44

4. Quantum Leap: Common minimum standards instead of forum regit actum 44

B. Cross-border admissibility of evidence gathered in a merely domestic context $\quad 45$

Notes 49 

Distinguished rector, dean,

Dear colleagues,

Dear family and friends,

Ladies and gentlemen,

"There are times when a commentator wishes the EU would sit still long enough to allow itself to be analysed". ${ }^{1}$ Back in 1999, I used this phrase from an article by Bill Tupman as a side quote in the book version of my Ph.D., in which I had conducted a critical analysis of five years of EU negotiations on mutual legal assistance (hereafter: MLA) in criminal matters. ${ }^{2}$ The object of my research - the EU, in making criminal policy - had behaved like a subject, choosing its own path, organically and often without too much logic, quite unpredictable in its constant movement. A member of my examination committee, during the defence of my thesis, had warned me that, if I were to continue studying EU criminal law (cooperation), my career would be much like a non-stop challenge to catch a moving train. She proved right. The EU doesn't sit still.

Some love is forever, though, and for me, this is among others true for EU cooperation in criminal matters. So I continued to critically study every single move concerned the EU has made, ever since, be it no longer as a distant, supposedly neutral researcher. Producing knowledge and insights about the past, largely having merely theoretical and potential relevance for criminal policy making at EU level only, wouldn't have felt satisfactory any longer. I chose therefore to approach my research subject differently, in that I started to study it from more closely, even from within, and to interact with it, walk with it, talk with it, while it continued to move, and to suggest it to reflect on its future steps, or even to choose a different path when arriving at a cross-roads. The EU, of course, has continued to live its own life, with everything to it. Still, I got the feeling that it has gradually shown more openness for the participatory companionship of and guidance and assistance by professional researchers, who aim at improving its criminal policy making and criminal law cooperation strategies by action research, primarily present and future oriented. I now try to study my research subject while trying to influence it, allowing me to study the impact thereof as well, undoubtedly while 
being influenced in my turn by the EU and by the EU and member states' judicial and police realities.

That is why today, I choose to quote from the early work of Bill Torbert, one of the icons of (organisational) action research: "Research and action, even though analytically distinguishable, are inextricably intertwined in practice. Knowledge is always gained in action and for action. [...] From this starting point, to question the validity of social science is to question, not how to develop a reflective science about action, but how to develop genuinely well-informed action" [emphasis added]. ${ }^{3}$ It summarizes well the way I have been trying to conduct research on the EU's criminal policy in the past decade back home, at Ghent University. Most probably, it also characterizes much of the scientific work we conduct there at IRCP, the Institute for International Research on Criminal Policy. It is not the better choice. It's a choice - the one that for me makes more sense and is more satisfactory. It's tiring, sure, but much fun, and fits my personality.

This type of criminal policy research necessarily builds on empirical data, tries to take stock of realities, both political and on the crossborder working floor. Our primary respondents are EU stakeholders, the European Commission, the Council, Eurojust and Europol as the main relevant EU agencies, their college members respectively staff and liaison officers, the member states, EU negotiators, ministries and central authorities, criminal justice actors in the member states, i.e. magistrates, prosecutors, judges, police officials and defence lawyers, as well as NGO's and fellow scholars and researchers.

The choice to focus today's lecture on cross-border investigation and evidence gathering in criminal matters in the $\mathrm{EU}$, is prompted by three reasons.

First, I deliver this inaugural lecture in accepting an extraordinary professorship of 'Evidence Law', so that there needs to be a clear-cut link. I choose to simply deal with subject matter that is forefront in the 'Evidence' course I teach in the Master in Forensics, Criminology and Law at the Faculty of Law of this University. Allow me to say, in this respect, that the absolute freedom I enjoyed in conceptualizing this course has made it easy to accept to teach it. It simply allowed me to 
logically extend part of my core research into academic teaching, the same way I enjoy this pleasure in Ghent. That is what all academics dream of. I am a lucky bird, no doubt. Consequently, there was no other option but trying to reflect this research-teaching match in today's lecture.

Second, choosing this topic allows me to illustrate why I feel at home in this new Maastricht environment. In some way, the dots connect. The current rector, Gerard Mols, has a strong scientific track record himself in international and European criminal law, among others on issues like the political offence (exception) and inter-state police cooperation. He was also among the very first in Europe to edit a volume (Dissonanten bij het Akkoord van Schengen) 4 in which the then newly concluded Schengen Implementation Convention (hereafter: SIC) of 1990 was critically assessed, including from a suspect's and defence perspective. His article in this volume together with Taru Spronken, one of my current Maastricht colleagues in the department of criminal law and criminology, titled 'Europa 1992, een moeras voor verdachte en verdediging?', ${ }^{5}$ was among the very first scientific articles I read in my early academic career, almost 20 years ago. I just embarked then, as a young researcher on the topic of legal protection in the context of European cross-border cooperation in criminal matters. ${ }^{6}$ The article of Mols and Spronken has certainly helped me in making and keeping the concern for an adequate legal status of suspects and defendants in cross-border proceedings a core axis of my research on the matter, together with the belief that such concern is not the antithesis of efficient law enforcement cooperation but needs to be combined therewith. In the mean time, I have been able to enjoy the pleasure to conduct joint research with Taru on the observance of procedural rights in criminal proceedings ${ }^{7}$ and effective defence in the EU member states. Both projects have provided ammunition for the EU Procedural Rights Roadmap, which is being rolled out since late 2009 as a means to create a better trust base for the principle of mutual recognition in criminal matters, which in its turn had become the cornerstone of judicial cooperation in criminal matters since the 1999 Tampere European Council. Her work brings more balance to EU criminal law. I see my position in Maastricht as an excellent opportunity to further enhance our joint research efforts. Needless to say that I get along very well with André Klip too, another of my 
current Maastricht colleagues. We have a joint passion for international and European criminal law for quite a while. We first met in 1993 in Utrecht, before he moved to Maastricht, and have ever since maintained professional and friendship relations. I think we have complementary profiles. Along the road, he started to focus more on international criminal tribunal law, whereas I primarily persevered in international cooperation in criminal matters. His EU criminal law research is strongly jurisprudence-based and more legal sensu stricto. Mine is more action-like, as sketched before, is criminal policy rather than strict legal research and tends to have an important empirical dimension. This I share with Hans Nelen, another Maastricht colleague - actually my head of department here. He is a professor in criminology, with a strong focus on empirical and evaluation research, dealing with subjects including law enforcement, both administrative and criminal, the tackling of financial and economic delinquency and of serious, corporate, organised and organisational crime. He also takes a keen interest in cross-border cooperation, especially at police level. I hope to provoke more collaboration with him too by holding this lecture. He may not be aware of it, but his early work at the Research and Documentation Centre of the then Ministry of Justice in the Netherlands (WODC), on the economy of drug careers, ${ }^{8}$ was a primary source of knowledge in the context of my very first research project in Ghent, in 1992, on the relation between drugs and crime. ${ }^{9}$ As I said, certain dots connect today.

Third, the topic of free gathering and movement of evidence in criminal matters in the EU allows me to not only introduce myself to today's audience in my preferred research domain, i.e. crossborder investigation in criminal matters in the EU, but to do so on a moment that I feel I have sufficiently matured in it. Today I dare to present you my vision, which I like to believe is footed in EU and member state realities, balanced but at the same time without too much compromising, and which I hope may somehow revolutionize policies through sufficient out of the box thinking. Over the years, since my Ph.D. in 1999 on EU MLA in criminal matters, I have had the occasion to conduct many EU criminal law cooperation research projects, often funded by the European Commission. Today, I use the occasion to also content-wise connect the dots of these projects. The by far most interesting research project I have been able to conduct 
until date, is the Study on the future institutional and legal framework of judicial cooperation in criminal matters in the EU. The study, called for by the European Commission, ${ }^{10}$ and which really has been a joint effort of the core IRCP EU criminal law research unit in Ghent, was concluded just weeks ago. Conceptually, it builds on much of the EU criminal law research I have concluded or led at IRCP. The book, comprising the results, is forthcoming. ${ }^{11}$ Our original mandate has been to conceptually prepare the future of judicial cooperation in criminal matters - to sort of design an EU master plan for judicial cooperation, doing away with inconsistencies, incoherencies and lacunae that have been prompted by the organic development that has characterized the very domain. Not only does the study encompass all traditional judicial cooperation domains (extradition/surrender, MLA, transfer of prosecution, transfer of the execution of foreign sentences). It also covers the trans-border pre-trial supervision of suspects, the exchange of criminal records information, the taking account of previous foreign convictions in new proceedings, the cross-border protection and relocation of witnesses and collaborators with justice. It further addresses the future of Eurojust and assesses the need for a European Public Prosecutor's Office. All this proved to be impossible without radically thinking bigger, beyond the borders of judicial cooperation. We broadened our field of research (convincing the European Commission of the necessity thereof), resolutely adding police cooperation (including the future of Europol) to it, moving into the intersection between criminal and administrative law, juggling with intelligence-led approaches, information and intelligence sharing practices and intelligence actors that have set foot on criminal law territory, actively blurring traditional boundaries in order to see more clearly after it, in the pursuit of a renewed logic, coherence and balance.

Applied to the future of cross-border gathering and use of evidence in criminal matters, I want to share the following findings and thoughts with you today, ${ }^{12}$ exploring the possibilities and preconditions for enhanced freedom in gathering (i.e. during the pre-trial investigation stage) respectively using (i.e. during the trial stage) evidence in criminal matters in the EU. 
Obviously, the interpretation of the term 'evidence' will differ between both stages. While the discussion around the usability of evidence 'before court' essentially depends on the admissibility thereof (leaving aside here questions of evaluation or weighting of admissible evidence, which will remain an issue to be discussed before and decided by court), the term will be used in a more generic sense when exploring the issue during the pre-trial investigation stage. In the latter context, 'evidence' will refer to any information, data or objects that the competent authorities consider relevant in the intelligence process relating to, prevention, detection or tracing of, proactive and preliminary investigation into, or prosecution of punishable offences. 


\section{I \\ Free gathering of evidence}

The possibilities and preconditions for enhanced freedom in evidence gathering can be explored from various perspectives, outlined below.

\section{A. By whichever authorities, irrespective of the finality of their actions?}

By means of introduction, it is good to recall or point out that the contemporary landscape of cross-border EU cooperation in criminal matters in view of the gathering of evidence in the generic sense of the word is quite blurred in terms of authorities involved. Next to judicial authorities, acting with criminal justice finality, at least five more types of authorities can be distinguished, all capable of operating with an either criminal justice or administrative finality:

- police authorities are involved in criminal justice matters, but also in tasks with an administrative (public order) finality;

- customs authorities also have criminal justice related and administrative tasks;

- sometimes, administrative authorities also have the competence to impose sanctions for offences, next to their competence to sanction other administrative infringements;

- in addition, specific central authorities have been established or appointed with a specific mandate to act in international cooperation in criminal matters or to deal with (information exchange relating to) certain types of crime. It could be administrations within the ministries of justice, witness protection units, financial intelligence units, Europol national units, European Judicial Network (EJN) contact points, etc. Their work can easily be labelled 
as both or either having a criminal justice and/or administrative finality;

- finally, even if traditionally they ought not to operate with a criminal justice finality, intelligence services in several instances apparently do, or they at least contribute to actions carried out with such finality. Especially after 9/11, they do appear more and more in cross-border criminal law cooperation settings.

1. A matter of judicial cooperation, by judicial authorities only?

In denial of reality, as shown above, evidence gathering is often perceived to be a matter of judicial cooperation only. Most probably, this is due to the fact that evidence will ultimately have to stand the test in court, i.e. before a judicial authority sensu stricto. Even in the trial phase though, the admissibility of evidence should not (critically) depend on whether it has been collected by a judicial authority, but rather on the observance of procedural rules in collecting it. In the pre-trial phase, most definitely, evidence issues are a matter of much more than judicial authorities only.

When having a proper look at most cooperation instruments that judicial authorities may use in information and evidence gathering across borders (the 1959 Council of Europe (CoE) European Convention on Mutual Assistance in criminal matters (hereafter: ECMA); the protocols thereto; the SIC; the 1997 Convention on mutual assistance between customs administrations (hereafter: Naples II); the 2000 EU Convention on mutual assistance in criminal matters (hereafter: EU MLA); the protocol thereto; the Eurojust Decision; the 2006 'Swedish' Framework Decision (FD); the 2008 European Evidence Warrant FD (hereafter: EEW); the 2009 Criminal Records FD), the truth is that member states are allowed considerable discretion in indicating which authority they deem to be 'judicial' for the application of the instruments concerned. Practice shows that member states, next to judicial authorities, often assign central, governmental but also police, customs (and in a single member state case: even intelligence) authorities as 'judicial' or 'competent' authorities. Even typical 'judicial cooperation' is apparently largely a matter of much more than cooperation between 'judicial' authorities only. 
Not only the member states, but also the CoE and the EU themselves, in designing judicial cooperation instruments, have abandoned the demarcation line based on authorities decades ago - be it fragmentary and far from in a consistent fashion. Administrative authorities may be or are charged with criminal records information exchange (ECMA; Criminal Records FD) or may use judicial cooperation instruments when it comes to administrative offences (SIC; EU MLA; EEW). There is built-in flexibility of authorities (judicial or equivalent, police and customs) for a series of special cooperation forms, such as controlled deliveries, joint investigation teams (JITs), infiltration and interception of telecommunications (EU MLA). Such flexibility was radically taken over for law enforcement information exchange, by bringing judicial authorities under that label as well, in addition to police and customs authorities, be it that such information will be deemed ineligible as 'evidence before court' ('Swedish' FD). It has been recognized that the prosecutorial competency may be entrusted to a prosecutor, judge or police officer of equivalent competence (Eurojust Decision). Police, customs, judicial and other competent authorities have been subjected to the very same data protection rules (2008 Data Protection FD). It is sometimes recognized that it suffices for a decision by a non-judicial authority to be labelled as 'judicial' after validation by a judge, court, public prosecutor or investigative magistrate (2011 Draft Directive on a European Investigation Order (hereafter: Draft EIO)), much in line with the ambiguous 'for police use only' autonomous police information exchange under the SIC). Recently, no further distinction has been maintained between information contained in databases held by police or judicial authorities (Draft EIO). The picture has become very much blurred - to say the least.

Finally, the time has also come to do away with the recurring misconception that adequate data protection with regard to the exchange of data that have already been gathered, requires the involvement of 'judicial' authorities, as opposed to 'non-judicial' authorities. It suffices for data protection rules to be linked to the finality of data handling, regardless of the authorities involved. Consequently, data protection needs to be a joint matter of concern for any authority acting with criminal justice finality. It must be as stringent for all types of cooperation in criminal matters, regardless of whether judicial, police, customs, administrative, central (or, in some case: even intelligence) 
authorities are involved. One single data protection regime should bind all authorities involved in cooperation in criminal matters. The relevant EU legislation as it stands, confirms this. Often, even more attention is paid to data protection issues in instruments relating to law enforcement (cooperation) (e.g. data protection regulations in the 2005 Prüm Convention or the 2008 EU Prüm Decision, or with respect to the functioning of Europol) than in those regulating cooperation between judicial authorities (e.g. a single article on data protection in EU MLA). Additionally, the distinction between data protection rules applicable to judicial respectively police cooperation has been formally labelled as irrelevant in the Data Protection FD. Our freshly concluded Study on the future of international cooperation in criminal matters points out that an overwhelming majority of the member states (20) support the position that adequate data protection does not require the involvement of judicial authorities. From this perspective, it is e.g. incomprehensible that the exchange of criminal records is considered to remain a prerogative of judicial cooperation, thus depriving police authorities in many member states and - at least indirectly - Europol (which is even supposed to hold data on convicted persons) of essential information.

In conclusion, both at $\mathrm{CoE}$ and EU level, both in 'old' conventions and in 'newer' legal instruments relating to 'judicial' cooperation, the demarcation line between different types of authorities based on their nature/name has become extremely fuzzy. Upholding therefore that the pre-trial gathering of evidence in the generic sense of the word is a matter of judicial cooperation in criminal matters only, is a joke. It is a joint matter of various 'competent' authorities working with a criminal justice finality. Our study on the future of international cooperation in criminal matters largely supports this. Half of the member states do agree that the discretion allowed to define the scope of 'judicial' cooperation themselves is non-functional and ultimately even misleading. 1/4th of the member states - roughly these that have chosen to appoint only 'judicial' authorities as competent authorities for the application of judicial cooperation instruments - felt no need for a conceptual shift from 'judicial cooperation' to 'cooperation in criminal matters' from their own perspective. The remaining 1/4th finds that, since the CoE and the EU themselves have built in express 'authority flexibility' or accepted 'judicial' equivalence in very many 
instruments, traditional conceptions of 'judicial cooperation' being a matter of judicial authorities and information and evidence gathering being a matter of 'judicial cooperation' artificial and unworkable.

2. Distinction judicial vs police cooperation: Artificial, often counterproductive or useless

Yet, in many instances the EU tends to still uphold a strict distinction between judicial and police (used here as a generic term for police and customs) authorities, not only through treating judicial and police cooperation as two separate policy making areas (thus preventing both to reach their full potential), but also through many other artificial distinctions. Even if quite upfront and seemingly provocative as a statement, I believe the traditional distinction between judicial and police cooperation in criminal matters should largely be abolished. It creates confusion. Often, the distinction concerned is either inexistent, non-essential, unworkable or counterproductive. It is an anomaly, hindering the establishment and roll-out of a coherent EU criminal law policy. 'International cooperation in criminal matters should become the default concept, as was already pointed out before. Period. The EU reality is painfully different. Some highlights.

The most distressing example is undoubtedly the parallel yet separated existence and further development of Europol and Eurojust.

It is commendable that the Eurojust Decision refers to the Europol Decision for its mandate, making their mandate ratione materiae grosso modo the same. This makes perfect sense given that the support of police investigations can simply not be distinguished clearly from pre-trial investigate led by the public prosecution in most member states. However, the ongoing discussions regarding the mutual accessibility to each other's data systems (exemplified by the lack of Eurojust access to the crucial Islamic terrorism analytical work file at Europol), which, besides, diverge entirely ratione materiae in terms of classification, are exemplary for a criminal law policy which ultimately is bound to fail.

Many problems which will be up for EU negotiation in the near future (not in the least the adoption of a regulation as legal basis for both 
bodies) require a helicopter view, as opposed to an approach built on the nature of authorities involved. Unlike for their mandates, Europol and Eurojust differ significantly in working structure. Simultaneously, and with great flexibility and autonomy, the Eurojust College assumes the different roles which at Europol level are scattered between the director, the management board and the ELO Network. Moreover, Europol, since it has become a supranational agency, is increasingly subject to political control by the European Commission. On top of that, the Eurojust College members are allowed to form part of JIT's, either on behalf of Eurojust or on behalf of their home member state. It should be hoped that the future Eurojust Regulation, based on Article 85 TFEU, will not put an end to this flexibility and versatility; and that the future Europol Regulation will alleviate the structure of this agency.

Ideally both bodies should merge into one. This seems idle hope in light of the (politically explainable) split of the former directorate-general Freedom, Security and Justice in separate directorates-general Justice (Commissioner Reding) and Home Affairs (Commissioner Malmström). Notwithstanding that the Lisbon Treaty regrouped all justice and home affairs matters (for ten years, under the Amsterdam regime, asylum, migration and external affairs were treated from a community perspective, whereas justice and police policy remained predominantly intergovernmental, even if the Commission enjoyed a right of initiative), the split into two directorates-general has definitively separated the policy work around justice and police. Both Commissioners now have 'their' agency to further develop: one has Eurojust, the other has Europol. Given the different nature of both policies (put way too bluntly and oversimplified: freedoms and rights vs. security), a logical, consistent, functional and integrative future approach for Eurojust and Europol becomes rather unlikely in the short term. Politicians, and the agencies with the them probably, tend to get primarily self-centred and to develop territorial behaviour.

The distinction between judicial and police cooperation is not only maintained with regard to Eurojust and Europol. The distinction between both domains, policy-wise, is total. This prompted a series of inequalities. Some examples. 
With the US there is only a Europol-US agreement yet no EU-US agreement regarding police cooperation, while there is a Eurojust-US agreement and already in 2003 two EU-US agreements concerning judicial cooperation were concluded - among which one for MLA, encompassing the exchange of so-called judicial information (which is obviously often the same information the police are after).

On the judicial level, important efforts were made to improve the dayto-day cooperation practice through practical tools and mechanisms (EJN, the fiches belges, the European judicial atlas etc.), while the police practice would benefit just as much from this. The EU chose not to do this and consequently practitioners need to help themselves.

In the 'judicial cooperation' scheme, the EU has categorically opted for horizontalisation of the cooperation, introduced first in the SIC, then further elaborated in the EU MLA and today close to being fully implemented in the context of the mutual recognition principle (2006 Freezing Order FD, EEW, Draft EIO). The interstate (and political) character of cooperation has been abandoned; the obligatory and unique transfer and execution of requests through ministries and central authorities is largely in the past (not to mention exceptions such the UK Home Office or the regional IRC's in The Netherlands, which qualify as decentralized central authorities). Locally competent authorities cooperate with each other as much as possible, in an ever more real European area of justice. Regarding police level cooperation it is striking that for too long (leaving the 'Swedish' FD and the availability principle aside) the attention was almost exclusively focused on central models/databases linked up with national units (Europol National Units, NSIS, Sirene bureaus, Interpol NCB's etc.)

A European Criminal Records Information System (ECRIS) has been designed for judicial cooperation in criminal matters, without any direct involvement or relevance for the police, which was already criticized above. Together with Unisys, IRCP will now embark on a new study - unsurprisingly called for by the directorate-general Home Affairs - 'on possible ways to enhance efficiency in the exchange of police records between the Member States by setting up a European Police Records Index System (EPRIS)' ${ }^{13}$ In our action-research capacity, we will try to convince policy makers of the necessity to think 
bigger, in designing EPRIS beyond something for police authorities only, to functionally link it with ECRIS, to conceptually confront it with the direct access to databases under the Prüm regime and to allow for conditioned access rights for Europol and Eurojust.

In conclusion, despite many counterexamples, on crucial points a strict policy distinction is maintained (if not stirred through the split in directorates-general) between the so-called judicial and police cooperation in criminal matters. Ultimately, that hinders the development of an efficient justice policy, fully involving police work with a judicial finality.

\section{Limited necessity for 'judicial' safeguards}

On the one hand, the EU is inconsistent in keeping a clear distinction between administrative and criminal justice finalities. As shown in the previous paragraphs, the EU very often stresses the demarcation, entirely disregarding it on other occasions.

On the other hand, the EU omits to clearly indicate when the distinction between judicial and non-judicial does matter. Whereas traditionally judicial prerogatives were assumed (without necessitating explicit reasons or motivation), lately (in particular the last decade), when drafting the so-called judicial cooperation instruments, the EU has almost systematically given the member states carte blanche by allowing them to appoint the 'competent' authorities themselves. In itself, this flexibility is not a bad thing, quite the contrary: it supports the shifting focus from authorities involved to the finality with which they act. However, in a few instances, 'judicial' safeguards seem to be necessary: not necessarily in the form of appointing judicial authorities as competent authorities, yet through a right to a legal remedy for the person involved.

In domestic contexts, in light of the ECHR, the ECtHR jurisprudence and the EU Charter of Fundamental Rights, it can hardly be doubted that the involvement of judicial authorities (or at least of equivalent authorities or authorities whose decisions have been validated by judicial authorities) is a necessity when taking coercive measures (which likely impact on the right to property) or measures which are 
intrusive to the right to privacy or data protection in particular. In the context of our study on the future of international cooperation in criminal matters, almost all member states confirmed this position (regardless, that is, of which authorities would execute the measure on the ground).

In evidence gathering cooperation contexts, our study on the future of international cooperation shows that, not only for sensitive and intrusive techniques such as controlled deliveries and infiltration for which the EU MLA expressly allowed for entrusting them to police or customs authorities, but also for the interception of telecommunications, for which the EU MLA required a domestic order legitimately issued in the requesting member state by a judicial or 'equivalent' authority, averagely half of the member states have appointed nonjudicial authorities as the 'competent' authorities.

It seems therefore that half of the member states consider the type of authority non-determining from the perspective of compliance with 'judicial' safeguards as required by the ECHR, the ECtHR or the Charter. Apparently, only the procedures by which authorities act, matter. I suggest the EU to take stock of this reality and to radically shift the focus to the procedures by which judicial, so-called equivalent, police or customs authorities should act and to the judicial remedies that need to be in place in taking certain investigating measures.

The approach followed in the EEW and in the Draft EIO is commendable from this perspective. Both instruments introduced an obligation for member states to foresee in judicial remedies for those measures involving coercive measures, equivalent to those, which would be available in a similar domestic case to challenge the investigative measure in question.

As to the nature of the bodies carrying out the judicial review, the name tag they carry seems again of secondary importance only. In the context of the EEW for example, it is perfectly conceivable that an administrative authority would take on this task. Yet, as stated above, as little as the name tag matters, as much do the procedural safeguards which are applied by those bodies; as long as they abide by criminal 
procedural safeguards and grant the subject a fair 'judicial' review of the decision, the nature of the authority is of minor importance.

\section{B. Decisive marker: Criminal justice finality}

Notwithstanding the reservatory 'judicial' safeguards that need to be in place, the finality with which authorities act - as opposed to their nature - should become the decisive and sole demarcation criterion for consistently delineating the field of 'cooperation in criminal matters'. The EU has recognised this fact for decades; unfortunately only indirectly and on an ad hoc basis. Lack of respect for this demarcation line is problematic in light of the separation of powers, the procedural guarantees in criminal matters and data protection regulations.

In the context of administrative offences the finality distinction has been made explicit at EU level since the SIC, recognizing for the first time that administrative authorities too can act with a criminal justice finality and thus can be brought within the scope of cooperation in criminal matters in as far as their decisions are subject to an appeal before a judge also competent in criminal matters. There is only one legitimate cross-over situation when it comes to keeping a strict separation between criminal justice and administrative finalities: criminal justice information can and should, whenever it is useful in preventing an immediate and serious threat to public security, be shared with the competent (administrative or intelligence) authorities.

\section{Part of the EU acquis}

I consider it essential to further maintain and where no longer or inexistent (re)introduce a strict separation between criminal justice and administrative finalities. My firm position is rooted in respect for the separation of powers, procedural rights protection and data protection. I will also illustrate how the blurring of boundaries between criminal justice and administrative finalities endangers democracy itself.

It is somehow sad, though, that such elaborate argumentation must be given to begin with. Just like the default position that 'judicial' 
cooperation is more than cooperation between judicial authorities (supra), the existence of the distinction between criminal justice and administrative finalities is supported through the very legislation of the EU itself. In several cooperation instruments adopted in the past decades (ECMA, EU MLA, 'Swedish' FD, Data Protection FD), it has been recognised that cooperation in criminal matters is a matter of cooperation between authorities, aimed at the prevention, detection, tracing, prosecution, punishment etc of punishable offences. It is a pity that this has only been the case in a fragmented way, ad hoc, using divergent wording, not in all relevant cooperation instruments and sometimes for specific investigative measures only. It is my conviction is that the finality of action by authorities must become the primary, resolute demarcation line for international cooperation in criminal matters in the EU. The outdated authority-based policy-making, reasoning and practice should make way for the introduction of a new, clear, unambiguous focus on protecting the integrity of cooperation with a criminal justice finality.

\section{Lack of finality demarcation problematic}

\section{a. Separation of powers}

Despite the fact that the demarcation line between the judiciary and the executive keeps fading and the grip of the latter on the former tightens, the separation of powers remains the cornerstone of modern and democratic public law. Criminal law constitutes a social contract between government and civil society and consequently the fight against criminality is a prerogative of the government, yet not every segment of government. The task to fight criminality is reserved to the judiciary and the police judiciaire (i.e. police when they are acting with a criminal justice finality), customs or inspection authorities (i.e. inspection authorities when acting with a criminal justice finality). These authorities are kept in check by the rules of play which protect civil society against disproportionate or arbitrary investigative behaviour. Following the principle of the separation of powers those rules of play are set by the legislator.

The role of the government, of the executive, and of the administrations, administrative authorities or other actors which resort under the 
latter's power carries a fundamentally different finality. In essence, the executive has a fundamentally different function than fighting crime. It monitors public order and security (and steers the administrative police in that regard). For that aim, it traditionally disposes of a civil and military intelligence service, is responsible for the shaping and implementing of the criminal justice policy and carries the administrative responsibility for the adequate functioning of justice and police. In other words, the executive acts with an administrative as opposed to a justice finality - a distinction stemming from the very principle of separation of powers. ${ }^{14}$

\section{b. Procedural guarantees applicable in criminal matters}

The fight against criminality carried out by justice and law enforcement authorities acting with a criminal justice finality can policy-wise be broadened somewhat through involving administrative or other actors. However, it is crucial that such broadening does not intrinsically undermine the very philosophy underlying the social contract, i.e. that the enforcement of criminal justice norms is a matter for the judiciary and not for the government. This is logical given that fighting criminality is limited by the procedural guarantees applicable in criminal matters, guarantees which have been subject to a delicate and gradually evolving balancing exercise between the interests of the individual and the public interest. This balance is alien to acts done with an administrative finality, and rightly so. Whereas criminal law has an intrinsically punitive character, the administration's aim is to assess and eliminate threats against the government, the society and the security, without affecting individuals in a punitive manner. The administration is not designed to punish the individuals which caused the threat and consequently operates under a fundamentally different regime. Indeed, not the rights of the individuals but the rights of the apparatus are the primary concern.

In those cases where the administration does step in the criminal law terrain, it has to acknowledge the criminal justice logic of acting in that context, and doing so brings about consequences. The latter is precisely where things go wrong. All too often administrative detours are sought in order to avoid the 'burdens' which go hand in hand with acting with a criminal justice finality. Procedural guarantees 
applicable in criminal matters are considered to be hindering the full coming into being of the novel 'right to security' which has so successfully been sold to the citizens. Two examples.

The declaration of the UK regarding the rules of play for the crossborder interception of telecommunication in criminal matters in the EU MLA is a good case-study. It was already clear that in the UK governmental entities can give orders of interception to police and custom authorities. When the official aim of such orders is to trace severe offences, the UK accepts the applicability of Article 20 EU MLA. This also applies when such orders are given to intelligence services, when they officially act in support of a criminal investigation as determined in Article 20. Leaving aside how peculiar the resolute and direct involvement of intelligence services in criminal investigations may be, the good news is that in such cases the criminal justice safeguards apply. In other words, even intelligence services can form part of the criminal justice process, as long as they behave as actors within the criminal justice chain. Authorities do not matter, finalities do. So far this example subscribes the proposed key notion of 'international cooperation with a criminal justice finality'. The explanation for this mechanism however, has a downside. Naturally, the real intention behind the UK declaration was to secure the practice whereby interception orders are given to intelligence or security services when they do not formally act in support of criminal investigations and would thus stay outside of the scope of the EU MLA. As such this does not seem problematic: acting without criminal justice finality does indeed not require the application of criminal justice safeguards. What is problematic, however, is this: intercepted information which is collected with a primarily administrative aim can without hindrance be re-channelled to investigations with a criminal justice finality, with the creative justification that the criminal justice finality is only secondary. Echelon activities, to be precise, needed to be kept out of range of official reproach, even when they produce useful information for dealing with terrorism or organised crime.

Another example concerns the cross-border execution of undercover operations in criminal matters under the EU MLA. Prior to this arrangement, justice and police were conducting such operations in a legal vacuum (not to say illegally), facilitated through the International 
Working Group on Undercover Policing. As such it was positive that a 'regulated' alternative to this practice was created. However, considering the criminal justice scope of application of the EU MLA, the new provisions did not produce any impact on the cross-border activities of intelligence services, which kept using the International Working Group as a tool for their activities and could and still can channel the acquired information into the criminal justice sphere.

Also The Netherlands seem to care marginally only about mixing up criminal justice and administrative finalities. Information sharing between authorities acting with criminal justice and administrative finalities has been proclaimed the new best practice, it seems. It suffices to refer to the BIBOB legislation (Bevordering Integriteitsbeoordelingen door het Openbaar Bestuur), the Regional Information and Expertise Centres (RIECs) that have been established in support of the 'administrative' approach to organised crime or the Amsterdam Emergo project, making data mining and data sharing between fiscal, administrative and criminal law enforcement authorities a standard practice. Effective. No doubt. Problematic. Definitely.

Our study on the future of international cooperation in criminal matters shows that (only) three member states have chosen to explicitly bring telecommunication interceptions and undercover operations with criminal justice finality by their intelligence services under the scope of the EU MLA, thus providing a procedural guarantee framework that equals that in criminal matters.

These examples show that, at least in some member states, the situation is blurred, with a potentially significant cross-border impact. It certainly is blurring in other member states too, reinforced by $9 / 11$ in particular. Hence, a reflection about cross-border information or evidence gathering is in vain if it does not aim to unravel the blurred line between criminal justice and intelligence work. Clear EU action in this regards is long overdue. A choice must be made to either clearly apply the relevant provisions to intelligence services when they are acting with a criminal justice finality (be it directly or indirectly) or to clearly delineate the limits of competences of intelligence services (and thus bar them from gathering information or acting when these acts would have a direct or indirect criminal justice finality). The latter 
seems politically unrealistic since it entails a direct intervention in the national law of the member states. Therefore, the former is the only solution at EU level: instead of defining the scope of instruments dealing with international cooperation in criminal matters based on the authorities involved, it should be defined based on the finality with which they act. In doing so, if intelligence services are (directly or indirectly) acting with a criminal justice finality, it will be guaranteed that the necessary accompanying criminal justice safeguards apply. When other authorities than the traditional ones want to take part in the enforcement of criminal law, they need to be bound by the same - instead of less - rules of play. ${ }^{15}$ This course of action received overwhelming support in our study on the future of international cooperation in criminal matters. Even the second option, being the clear delineation of competences of intelligence services in that they would be barred from gathering information or acting when these acts would have a direct or indirect criminal justice finality, gained broad support.

\section{c. Data protection and purpose limitation ${ }^{16}$}

The purpose limitation or finality principle constitutes a core principle of data protection law and is recognized as such by the EU. This principle does not exclude the possibility for entities to gather private information with a criminal justice character, but it prevents those entities to use such information for purposes which do not have a criminal justice character. It thus prohibits the practice of entities providing such information to other entities, unless the use of that information has a purely criminal justice finality.

Unfortunately, there are numerous examples within EU law eroding the purpose limitation principle. I suffice giving two. The first example can be found in the Data Protection FD: even though Article 3 FD Data Protection stresses the purpose limitation principle, it is being put up for grabs later on in the FD (Article 11). The default position outlined in Article 3 is that personal details can only be processed for the purpose for which they have been collected. The second paragraph specifies under which conditions they can be passed on for different purposes and Article 11 contains an enumeration of those other purposes. A close reading of Article 11 reveals a breach of the purpose 
limitation principle. While provisions a) and b) can be justified, provision d) renders the purpose limitation meaningless: the information can be used for any other purpose than for which it was originally collected, if the member state or the person concerned consent to this. The consent of the person concerned (who can freely dispose of his/her own privacy) could indeed be a viable exception, but only if that consent - and with it, the purpose limitation principle - cannot not be circumvented when the member state consents instead. The second example concerns the second Schengen Information System (SIS II). In the SIS II, breaches of the finality principle were legally anchored at EU level: information gathered by security services can smoothly be channelled to the criminal justice sphere, even where no criminal justice procedural safeguards have been respected in gathering the evidence.

These examples underpin the importance of respecting finalities in the context of information fluxes from the criminal justice to the administrative sphere and vice versa. This can also be applied to administrations which, for issuing certificates or in the context of public procurement policy, need access to information regarding the involvement of persons concerned in certain criminal offences.

\section{Flexible finality demarcation?}

\section{a. Administrative sanctions: Only seemingly a cross-over}

The separation of finalities forms a - silent - part of the EU acquis. This follows from the analysis of several provisions above. Through the analysis it became apparent that the EU traditionally focuses on the aim of the actions in the sense that they need to be taken in the context of a criminal investigation, or on the nature of the offences, or on both. The cooperation in criminal matters at EU-level has traditionally been limited to the context of criminal offences. The fact that within the EU there is a considerable diversity in naming certain misdemeanours as being of a criminal justice or administrative nature, threatened to hinder cooperation considerably. Indeed, member states where petty offences were not labelled as criminal could not obtain cooperation for those offences, given that they did not 
fall within the realm of the cooperation instrumentarium. Hence, this constituted a break on cooperation, but a break which was perfectly justifiable in light of the criminal justice finality: administrative offences are traditionally placed outside the criminal justice sphere and they are consequently treated in a very different framework, without containing the procedural safeguards applicable in criminal matters. This means that in general the detection, prosecution etc. of administrative offences usually happens with an administrative - as opposed to criminal justice - finality.

Building on the SIC acquis, the EU MLA has extended MLA under certain conditions to the category of administrative offences. This is understandable, given the relatively large number of offences which is initially handled by administrative authorities in several member states. Examples are the Ordnungswidrigkeiten in Germany or the Dutch traffic offences under the Lex Mulder. Crucial is that the EU added a condition which guarantees that the member states will indeed apply the procedural guarantees which form part of criminal procedures when detecting and/or prosecuting such administrative offence. In concrete terms the condition is that - if member states wish to bring the detection and prosecution of administrative offences within the realm of the EU cooperation instrumentarium - there is an appeal possibility before courts which are (also) competent in criminal matters.

This system extends the concept of criminal justice finality, but it is not in violation of it, quite the contrary. The baseline of the reasoning, namely that when the purpose of the acts is the detection or prosecution of criminal offences the procedural safeguards from criminal procedures should apply, still stands. Through imposing the condition of an appeal before a court competent in criminal matters the prosecution of those administrative offences is brought inside the criminal justice system and consequently under the application of the necessary procedural safeguards. In other words, the extension confirms the default position.

Therefore, it is crucial not to deviate from the criminal justice appeal condition. The only nuance - it is more of a clarification - can be that the competent appeal judge would have an administrative 'name tag', 
but could treat certain administrative offences in accordance with the procedural safeguards applicable in criminal matters. In those cases the philosophy that the finality of the authority's actions outweighs its name-tag needs to apply consistently: as long as the authorities involved fit the criteria imposed by the ECtHR ${ }^{17}$ (and only then), it should be possible to bring administrative offences within the realm of the extended criminal justice finality. A translation of this position in the applicable legislation could speed up the mentality change from focus on authority to finality, and could avoid useless or illogical bans from international cooperation in criminal matters. This being said, given the importance of the appeal condition, a restrictive interpretation remains necessary.

\section{b. Prevention of an immediate and serious threat to public security: A legitimate cross-over}

To favour a distinction between criminal justice and administrative finality is one thing. To lose touch with reality another. Sense of reality indeed leads to the recognition of a legitimate link between both finalities, namely when there is 'an immediate and serious threat to public security'. In this case it should remain possible to exchange certain information or to take actions in disregard of the demarcation of finalities.

Throughout the EU instrumentarium many exceptions related to public security considerations can be found (e.g. in the 'Swedish FD, the EEW and the Criminal Records FD). They all contain the aforementioned limited exception on the finality principle: where the information can normally only be transmitted for the same (or a closely related) aim as for which it was originally collected, the information can also be transmitted for other purposes, under the condition that there is an immediate and serious threat to public security. This public order exception is not only acceptable but even necessary in those instances where a strict finality separation would be an impediment to the prevention of a threat to public security. However, it needs to be stressed that this link between administrative and criminal justice finality has to be applied restrictively. The Data Protection FD for example creates a much too loose link between both finalities: it is sufficient that the original member state consents 
(the consent of the person not being required) in order to justify the usage of the information for any purpose thinkable. This entails an unacceptable broadening of the public security exception. If the $\mathrm{EU}$ is indeed as serious about the finality principle as it claims in several instruments, limits need to be set consistently to the allowed deviations. Information needs to be able to flow from criminal justice to administrative sphere when there is an imminent threat to public security, but only then.

Regrettably, 'creative' deviations are gaining increasing popularity in several member states and also in the EU legislation, in particular where terrorism or serious crime are concerned. This evolution threatens to do away with the very pillar on which the EU legal area was built, being the respect for the integrity of procedural guarantees. This in itself might very well represent an even bigger threat to the public interest $-\mathrm{a}$ threat more immediate and serious than many (want to) see.

\section{Irrespective of the offence (definition) concerned?}

Traditionally, MLA was not dependent on double criminality but in the execution of letters rogatory in fine of measures as (house) search and seizure (ECMA, amended by Article 51 SIC). Later followed other techniques, such as the interception of telecommunications (EU MLA), access to banking transactions and account information and the monitoring of bank accounts (Protocol EU MLA) and the cross-border taking of DNA samples (Prüm and Prüm Decision). Generically speaking, one could say that no coercive or intrusive measures will be executed by a requested member state unless the facts for which they have been requested constitute a punishable offence on its territory.

The question whether a(n) (partial) abandonment of the dual criminality condition in these cases might be pursued in view of rendering MLA more effective, has been debated for a long time. It was not until the EEW that, where the gathering of existing evidence would require (house) search or seizure, the dual criminality rule was dropped for the '32 mutual recognition offences', traditionally used for that very 
purpose in preceding mutual recognition instruments. This standard approach, which in itself is conceptually problematic, ${ }^{18}$ was simply further pursued in the Draft EIO, turning the abandonment of the dual criminality rule for the 32 mutual recognition offences into a general principle. If the instrument would be adopted in 2012 (which is hoped will not happen, for reasons explained later), the result will be that dual criminality will only continue to be an 'obstacle' for the measures mentioned above where the requesting thereof is for another offence than the 32 in the list, according to the law of the requesting member state, that is.

\section{Any investigative measure?}

Obviously, a mandatory execution of any investigative measures requested will often require the requested member state to go beyond the limits of its own legal system. When it comes to the (execution of) measures as (house) search and seizure (Article 51 SIC), interception of telecommunications (EU MLA), access to banking transactions and account information and the monitoring of bank accounts (Protocol EU MLA) and the cross-border taking of DNA samples (Prüm and Prüm Decision), a consistency test of the requested measure with the law of the requested member state is the rule.

Execution can be inconsistent with the law of the requested member state in that it surpasses the scope ratione auctoritatis because the requesting or issuing authority (or the authority having validated the request or decision) is not a judge, a court, an investigating magistrate or a public prosecutor, whereas in a similar national case the measure(s) would need to be ordered or supervised by such an authority (see e.g. the explicit non-execution ground in the EEW). When doing away with the artificial distinction between judicial and police authorities, and provided the necessary 'judicial' safeguards are in place, this type of inconsistency should no longer constitute an obstacle for cooperation.

However, execution can also be inconsistent with the law of the executing member state in other respects, for which it seems harder to easily find a solution. 
The requested investigative measure may e.g. surpass the scope ratione loci, ratione temporis or ratione personae (because the measure(s) can only be taken for a more limited category of persons). For the latter scope, the link with corporate criminal liability issues and the possibility to execute investigative measures is obvious. On the basis of the Commission-funded Study on the liability of legal persons for offences in the national legal systems of the member states of the European Union, which IRCP will conclude in early 2012, we hope to be able to trigger a breakthrough on the matter, in the sense that inconsistencies relating to diverging corporate criminal liability issues should by no means frustrate cross-border cooperation. More difficult to overcome are inconsistencies relating to the fact that in the requested member state, certain investigative measures may be limited to a more narrow category of natural persons in terms of for example their age, procedural status and definition.

The requested investigative measure may also surpass the scope ratione materiae, which is linked to the double criminality requirement (supra). This will not be easily solved. Even after a year of negotiations, the Draft EIO only rules out refusal on this basis when it comes to one of the 32 mutual recognition offences.

The chief novelty that the Draft EIO introduces, i.e. that any measure requested (except the setting up of a JIT), even if not expressly regulated in MLA (which until now is covered by the flexible and smart obligation for member states to afford one another the 'widest' measure of mutual assistance as embedded in Article 1 ECMA), will have to be executed, is therefore bound to fail. Notably, the draft EIO does not resolve inconsistency issues ratione loci, ratione temporis or, beyond the 32 mutual recognition offences, ratione materiae. Its belief that member states will further be prepared to systematically execute measures in case that these may be simply unknown to their legal system, seems quite naive, to say the least.

\section{E. For free?}

There is nothing like a free lunch. It is very unlikely therefore that furthering the stringency in cooperation through a radical introduc- 
tion of mutual recognition in current MLA (as envisaged in the draft EIO) is realistic. Especially not if - as in the draft EIO - the idea is to bring any investigative measure under a stringent mutual recognition regime, softened only by a duty on the side of the requesting or issuing member authority to not ask for the taking of measures if this would be disproportionate in light of the (limited) seriousness of the offences or the (limited) importance of the case concerned. Such mechanism lacks credibility of course. It only appeals to self-restraint on the side of requesting authorities, ruling out any possibility for the requested member state or authority to refuse or not execute where it would find the taking of the measure(s) a disproportionate or too much of a burden in terms of financial or operational capacity. The possible implications in terms of operational or financial capacity for the executing member state in executing under a stringent mutual recognition regime may be very substantial and give rise to even more problems than under the current regime, the default rule of which is that capacity issues do not constitute a refusal ground, each of the cooperating parties bearing its own costs (ECMA). Already today, $\mathrm{a}(\mathrm{n})$ (alleged) lack of capacity is not seldom frustrating MLA. An empirical study, conducted by IRCP in 2009-2010, on the execution of Belgian MLA requests by The Netherlands, provides convincing proof thereof. ${ }^{19}$ The need for a debate on capacity is urgent, especially since - with the Draft EIO - the fetish of mutual recognition is about to radically change MLA and strangulate criminal justice systems either financially or in terms of operational capacity.

\section{Financial capacity}

In the study on the future of international cooperation in criminal matters, roughly half of the member states have declared that financial capacity should somehow constitute a refusal ground. Based on those results, we have designed three future policy options, which were tested either in the context of that study or the preceding study on EU cross-border gathering and use of evidence in criminal matters. A first option could be to further develop the existing provisions on cost-sharing between member states. A second option could be to put the financial burden completely on the requesting or issuing member state. A third could be to allow the executing member state to suggest less costly alternatives. Each of them are further explored below. 


\section{a. Cost-sharing}

In the study on the future of international cooperation in criminal matters, half of the member states have pointed out that financial arrangements do matter in international cooperation. Financial uncertainty is said to cause delays in cooperation and to undermine trust between cooperating authorities.

As a way to make the financial arrangements clear-cut at the onset of any cooperation initiative, it seems worth considering to introduce a cost-sharing principle that mirrors the benefit-sharing principle that has been included in the 2006 FD on the mutual recognition of confiscation orders. The latter FD has introduced the splitting of revenue from the execution of confiscation orders surpassing the amount of $€ 10.000$ on a 50/50 basis between the executing and the requesting member state. Only if the revenue is not very significant (i.e. below $€ 10.000$ ) it will accrue to the executing member state. This may not seem directly relevant for the analysis of financial issues that executing requests or orders for cooperative measures can entail. However, the possibility of broadening this approach embedded in the FD Confiscation as to the 50/50 division of profits to a possible future $50 / 50$ division of substantial costs in executing MLA requests or mutual recognition orders, deserves further reflection and has therefore been tested in the study on the future of international cooperation in criminal matters. Although most issuing member states do not ask the executing states to share the benefits and benefits are not often shared when there is no obligation to do so, benefit-sharing is considered to be a fair option and especially so when the investigation is exceptionally costly or when benefits are exceptionally high. The $€ 10.000$ threshold could be used therefore, but is probably quite high. Surely, a symbolic threshold system will not be sufficient to cope with the upcoming problems that the Draft EIO is likely to produce.

\section{b. Costs borne by the requesting or executing member state}

Provisions stipulating that the costs should be borne by the issuing member state, unless the executing member state has waived its right for a refund already exist as an exception to the general rule and can 
be found in various instruments, relating to either costs of substantial or extraordinary nature, to certain costs that the execution of requests for hearings by video conference can entail or to telecommunication interception costs (EU MLA), or to expenses for fees paid to experts (Naples II).

The study on the future of international cooperation in criminal matters showed that it is highly exceptional for an executing state to waive its right for a refund so that in the above mentioned situations (video links, telecommunications operators and expert fees) costs are effectively borne by the issuing state as an exception to the general rule. Member states also thought that the costs of undercover operations should be completely borne by the requesting member state. The draft EIO, merely copying the provisions of EU MLA relating to undercover operations, again proves to lack touch with reality.

\section{c. Suggest less costly alternatives}

Another option could be to allow the executing member state to suggest less costly alternatives. If specific expensive techniques and/ or equipment are needed in order to cooperate with the issuing state, alternative solutions may sometimes be provided for. The question arises to what extent it should be possible for the executing member state to suggest or to decide on less costly alternatives. It could be argued that an interdiction to suggest alternatives follows from a duty to apply the issuing member state's rules and procedures. Such interdiction, though, may be considered a bridge too far by the executing member state, because conflicting with its own interests, rules and procedures.

Responses, obtained through the study on the future of international cooperation in criminal matters, show that a large majority of member states sometimes suggest alternatives in reply to explicitly requested formalities and procedures, with $1 / 3^{\text {rd }}$ of the member states specifically referring to situations where these formalities and procedures place a disproportionate burden on their capacity, over $1 / 5^{\text {th }}$ of the member states referring to situations where the requested formalities and procedures are believed not to be not necessary and close to half 
of the member states referring to situations where they believed that the same results could be achieved in a more speedy or less costly way.

Similarly, almost all member states thought it should be possible for an executing member state to suggest less costly alternatives. However, opinions were split on the issue who would eventually have to decide on whether or not an alternative course of action would be adopted and how this would affect the cost-sharing principle.

\section{Operational capacity}

Issues related to operational capacity are potentially an even bigger obstacle for smooth international evidence gathering in criminal matters than financial capacity issues. The executing member state may feel that the implications of the execution of a request or order in terms of operational capacity or resources would be too heavy and thus hamper the proper functioning of its criminal justice system. For example, it is very likely that extensive requests require a lot of working hours from authorities in the executing member state so that the latter considers the impact on its domestic workload disproportionally heavy or fears that (priority) domestic cases would be jeopardised. In the studies on the EU cross-border gathering and use of evidence in criminal matters and on the future of international cooperation in criminal matters, it was therefore assessed to what extent member states were likely to refuse the execution of requests for operational reasons, or if they felt that refusal for these reasons should be possible.

Although a majority of member states, both from the perspective of being the issuing and executing state, confirm that they are not often confronted with operational capacity issues, there is however a fair amount of member states $\left(1 / 4^{\text {th }}\right)$ that do argue that operational capacity issues are significant enough to start an EU level debate on how to precisely deal with this. One wonders what actually the negotiations on the Draft EIO are about.

Additionally, the question can be raised to what extent an aut exequi aut tolerare principle could prove useful, conceptually drawing inspiration from the traditional aut dedere aut iudicare and the more recent aut 
dedere aut exequi principles. In extradition or surrender cases, the unwillingness or inability of a member state to extradite or surrender a person as an obstacle for execution is overcome by the introduction of the aut dedere aut exequi principle, introducing an obligation for the member state involved to execute the decision itself. A parallel but reverse aut exequi, aut tolerare principle would mean that the executing member state is to execute the order of the issuing member state or alternatively (e.g. in case of operational capacity issues) tolerate the competent authorities of the issuing member state to execute the order themselves on the other member state's territory. Introducing this principle with regard to MLA would simply extend the current international cooperation acquis. The concept of allowing the active presence of foreign investigators on one's territory is known from the JIT and Naples II context, be it only to the extent that member have chosen to transpose the concept into their domestic law. The principle of tolerare, i.e. tolerating officers of another member state on one's territory, could be extended to those situations in which operational capacity issues would lead to difficulties in executing MLA requests. If necessary, the scope of the new principle could be limited to non-coercive or non-intrusive evidence gathering measures only.

Having tested the idea of aut dedere aut tolerare, it appears that almost all member states - in the context of JIT's or Naples II - allow officers of another member state to operate on their territory and that there appear no immediate constitutional hurdles for this to take place. Further, member states support the newly suggested principle as an acceptable future policy option, although most member states would limit its application to those aspects of cooperation that do not require the involvement of a judicial authority (whatever that is), and less than half of the member states to exceptional forms of cooperation such as cross-border surveillance and covert operations only.

\section{F. Without borders?}

A more radical choice would of course be to simply opt for a tolerare principle, by allowing the member states' authorities acting with a criminal justice finality to cross the internal EU borders in view of actively gathering evidence in other member states, respecting their 
local legislation and/or at least complying with agreed EU minimum procedural guarantees. Actually, this is exactly what the founding treaties envisage and have envisaged for a long time. Reference should be made here to Art. 89 TFEU, a provision which is an almost identical copy of Art. 32 former TEU, in existence since the 1997 Treaty of Amsterdam. After almost 15 years, one may assume that time has come to actually make use of this provision. Art. 89 TFEU foresees the possibility for the Council to legislate the conditions under which the competent judicial and police authorities of the member states can operate on each other's territories. If politically to big a step to envisage a possibility of active crossing of borders in search for evidence on an EU-wide scale, it seems that at least the Benelux should embark on creating this possibility. Seven years have lapsed since the Benelux Police Treaty. Time for a new impulse, I believe. It could solve many of the current issues in the Belgo-Dutch MLA cooperation reality and would allow the Benelux to again play a catalyst role in an EU of variable speed. 



\section{Free movement of evidence}

The entire question of the gathering of evidence becomes superfluous if in the end the obtained evidence will not serve any real purpose in trial due to inadmissibility. Currently, it remains completely unclear what happens in the end with evidence gathered or obtained on the basis of cross-border cooperation. None of the existing MLA or mutual recognition instruments even addresses the issue, save for Naples II, creating an opening towards per se admissibility of evidence, leaving member states the discretion to use it or not though.

\section{A. Mutual admissibility of evidence gathered following a cooperation request}

\section{Forum regit actum}

The forum regit actum principle (FRA) has been introduced in the EU over 10 years ago (EU MLA). It was supposed to accommodate concerns of admissibility of evidence that resulted from foreign evidence gathering along the then known cooperation principles.

When assessing the techniques used to accommodate concerns of admissibility of evidence, the duality between applying the rule of locus regit actum or the rule of forum regit actum is striking. Originally, MLA between the EU member states had its sole legal basis in the ECMA. That 'mother treaty' notes in its Article 3 that the requested state shall execute an MLA request in accordance with its own rules and regulations, i.e. according to the locus regit actum principle. The location where the investigative measure would take place was the decisive element in determining applicable law. This means that a request made by one state, for which the legal 
basis can be found in the ECMA, will be executed according to the law of the requested state. However, as a result of differences between national procedures, sometimes information gathered in one member state cannot be used in another member state because the way the information was obtained does not fit the national procedural requirements. In the following years problems with the admissibility of evidence gathered abroad in the context of mutual legal assistance requests gained more and more attention. The fact that certain formalities or procedural requirements that are crucial when determining the admissibility of evidence where not complied with during the foreign evidence gathering process proved to be a significant hindrance to the effectiveness of foreign evidence gathering. Therefore, when developing an EU instrument to complement the existing CoE instrument, a solution was sought. As a result, the EU MLA now provides that the requesting state can ask the requested state to comply with certain formalities or procedural requirements that it deems essential under its national legislation. According to this forum regit actum principle, the member state receiving an MLA request must in principle comply with the formalities and procedures expressly indicated by the requesting state. The only derogation allowed is to the extent that this would be incompatibility with the fundamental principles of the law of the executing member state. The state where the forum i.e. the court is located, can since have a say in the way evidence is to be gathered, in striving for maximized admissibility chances of the evidence gathered.

\section{Conceptual flaws and weaknesses of forum regit actum}

Because the entire design of the evidence landscape and the instruments regulating the gathering of evidence via different investigative measures are currently under review, it is important to include a critical assessment of FRA therein.

From the very beginning is was clear that FRA had a lot of flaws and weaknesses and would not be capable of providing an adequate answer to the admissibility concerns. 
First, even though FRA is designed to accommodate the aspirations of requesting member states and their concerns with respect to the admissibility of evidence gathered upon their request, no commitment to accept per se admissibility can be found in the cooperation instruments. This means that a request to take certain formalities or procedures into account, does not entail the commitment to accept the admissibility of evidence gathered accordingly. In other words, an executing member state that puts a lot of effort in gathering evidence according to the requested formalities and procedures, has no guarantee that its efforts will we rewarded with the recognition of the admissibility of the evidence it has gathered. As a result, FRA seems to remain but a tool for the requesting member state to impose its formalities and procedures upon the requested member state without having to commit to accepting admissibility of the evidence gathered accordingly.

Second, FRA only has a very limited admissibility-raising effect in the sense that it only seeks to ensure admissibility in a one on one relation between the requesting and requested member state. In doing so, it has no potential of ensuring admissibility within the entirety of the Union. However, undeniably, the possibility to adjust the way of gathering evidence is a opportunity to work towards a situation in which the admissibility of newly gathered evidence is accepted throughout the Union. Only an approach that ensures EU wide admissibility would really support and shape the evolution towards free movement of evidence. FRA intrinsically fails to contribute thereto.

Third, even in the one on one situation, the strength of FRA is relatively weak in the sense that it does not create a true and transparent situation in terms of the lawfulness of the way evidence was gathered, let alone the admissibility of evidence that is linked to that. Allowing one member state to request for certain formalities and procedures to be taken into account and therefore requiring another member state to take those formalities and procedures into account, runs the risk of undermining the status of either lawfully or unlawfully gathered evidence. 


\section{Quick wins}

In the study on EU cross-border gathering and use of evidence in criminal matters, two specific future policy options were tested, outlined below. As they both received support of almost all member states, they can be introduced almost right away.

The first option entails that information lawfully obtained by a member or seconded member while part of a JIT which is not otherwise available to the competent authorities of the member states would constitute per se admissible evidence under the national law of the member states concerned. Under the current regime, such information can only be 'used' in the latter.

The second option entails the introduction of the possibility for competent authorities from other member states that are lawfully present on a member state's territory while executing a request, order or warrant (e.g. as a seconded member of a JIT operating on the latter's territory, when present during a hearing or house search etc) to draft official reports having the same probative value under the law of the member state where they are present as if they had been drafted by the latter's own competent authorities.

\section{Quantum Leap: Common minimum standards instead of forum regit actum}

Beyond the above quick wins, and considering the conceptual flaws and weaknesses of FRA, one would expect that the current momentum to redesign the entire landscape of MLA and cross-border evidence gathering would be seized to drastically rethink the approach to tackle admissibility problems. Nothing like that. The Draft EIO simply copies the FRA principle from EU MLA, just like the EEW had done. Added value of the Draft EIO for the core issue in current EU evidence law, especially after the explicit new legal basis in Article 82.2.a TFEU for enhancing mutual admissibility of evidence in criminal matters between the member states legal : zero.

The only way to remedy things and tackle possible admissibility issues is via the introduction of minimum standards according 
to which evidence is to be gathered. This would mean that, if per se admissibility is aimed at, the information or evidence gathered following a cross-border request would have to be gathered according to commonly agreed minimum standards. This would do away with discussions on the lawfulness of the information or evidence gathering technique and subsequently, the evidence gathered would constitute admissible evidence before court in all 27 member states. Newly gathered evidence in a cross-border context would be subject to an irrefutable presumption of admissibility and consequently become eligible for free movement throughout the Union. So far, already $1 / 3^{\text {rd }}$ of the member states judges the FRA rule outdated and wants to see it replaced by the introduction of minimum standards, which they view as the only way forward. Another $1 / 3^{\text {rd }}$ is very much in favour of the idea but is hesitant as to whether minimum standards would be able to do away with the FRA principle altogether. When it comes to the level of the standards, member states suggest to base them on existing MLA regulations, backed up with standards that either surpass the ECHR/ECtHR standards or at least equal them. Evidence seized during a house search, if carried out in line with the standards in the Van Rossem case, would constitute per se admissible evidence. Evidence obtained through the interception of telecommunications, if complying with the rules outlined by the ECtHR in the Malone, Huvig, Kruslin, Klass etc cases, would constitute per se admissible evidence. Anonymous witness testimony, if complying with the standards laid out by the ECtHR in the Doorson, Kok, Visser, Kostovski, Windisch, Lüdi, Unterpertinger, Saïdi, Asch, Artner, Delta, Luca, Solakov etc cases would constitute per se admissibility. Etc. It may seem difficult an exercise, but it's doable. ${ }^{20}$

\section{B. Cross-border admissibility of evidence gathered in a merely domestic context}

When discussing the concerns related to mutual admissibility of evidence gathered abroad following a cooperation request, no concerns were raised relating to the admissibility of evidence that has been gathered in another member state prior to any request. That was a deliberate choice, because dealing with admissibility concerns related to evidence that already exists in another member state falls outside 
the scope of problems related to cooperation in criminal matters. It is not a cooperation problem, because the problem is not situated at the level of the cooperation mechanism that ensures the transfer of evidence from one member state to another. Rather, it concerns the use of evidence gathered in a merely domestic context. This does not mean, however, that the problem is irrelevant in reviewing the entirety of international cooperation in criminal matters. Therefore, the cross-border admissibility of evidence gathered in a merely domestic context, and more generally the possibility to attach an EU-wide effect to evidence that is gathered and perceived admissible in one member state - so that the admissible evidence would be considered admissible in all other member states - is separately addressed hereafter.

The easiest and quite pragmatic solution in fine of cross-border admissibility of evidence gathered in a merely domestic context, would obviously be to introduce minimum standards for evidence gathering all together, obliging member states to include them into their national criminal law systems and apply them equally in merely domestic as well as in cross-border situations. The legal basis required to do so is highly questionable, though. In a strict reading, the possibility in Article 82.2 TFEU to introduce minimum standards is limited to situations where such standards are necessary to facilitate mutual recognition of judgments or police and 'judicial' cooperation in criminal matters having a cross-border dimension. Consequently, problems originating from merely domestic situations such as the effect of evidence that was already gathered in such context, would fall outside the scope thereof. However, the (proposed) adoption of a number of instruments, such as the Directive on the right to translation and interpretation in criminal matters, the Directive on a letter of rights and the Draft Directive on the right to legal assistance (all urging the member states to transpose the obligations springing from them in both a cross-border and merely domestic context), shows that the scope limitation of Article 82.2 TFEU is not all that strictly linked to cross-border situations. From the political discourse of Commissioner Reding and from the contents of the above mentioned instruments adopted or proposed following the measures included in the Procedural Rights Roadmap, it can be concluded that - as long as member states are willing to agree thereto - it is possible to adopt minimum rules that are applicable in a merely domestic situation 
and therefore require member states to adapt their national law when necessary.

In the study on the future of international cooperation in criminal matters, the member states' willingness to extend the adoption of minimum procedural rules for evidence gathering beyond a crossborder context was tested. The prospects are surprisingly good: $2 / 3^{\text {rd }}$ of the member states explicitly indicate that such minimum procedural standards should not be limited to cross-border situations, and ought to also apply in merely domestic situations. Moreover, member states clearly understand the consequences of extending the choice to allow minimum standards to be adopted beyond cross-border situations. Over $4 / 5^{\text {th }}$ of them is aware and accepts that this will imply significant changes to domestic criminal procedural systems.

I have spoken. 



\section{Notes}

1 W. Tupman, 'Supranational Investigation after Amsterdam, The Corpus Juris and Agenda 2000', Information \& Communications Technology Law, 1998, 99.

2 G. VeRMEULEN, Wederzijdse rechtshulp in strafzaken in de Europese Unie: naar een volwaardige eigen rechtshulpruimte voor de Lid-Staten?, Antwerp-Apeldoorn, Maklu, 1999, 632 p.

3 W. TORBert, 'Why Educational Research has been so uneducational: the case for a new model of social science based on collaborative inquiry', in: Human Inquiry, a sourcebook of new paradigm research, P. Reason and J. Rowan (ed.), Chichester - New York, Wiley, 1981, 145.

4 G. Mols (ed.), Dissonanten bij het Akkoord van Schengen, Deventer, Kluwer, 1990, 167 p.

5 G. Mols and T. Spronken, 'Europa 1992, een moeras voor verdachte en verdediging?', in: Dissonanten bij het Akkoord van Schengen, G. Mols (ed.), Deventer, Kluwer, 1990, 36-60.

6 G. Vermeulen, T. Vander Beren, P. Zanders and B. De Ruyver, Internationale samenwerking in strafzaken en rechtsbescherming. Pleidooi voor een geïntegreerde nationale en internationale benadering, Brussels, Politeia, 1995, 386 p.

7 T. Spronken, G. Vermeulen, D. De Vocht and L. Van Puyenbroeck, EU procedural rights in criminal proceedings, Antwerp-Apeldoorn-Portland, Maklu, 2009, 116 p. See also: L. Van Puyenbroeck and G. Vermeulen, 'Towards minimum procedural guarantees for the defence in criminal proceedings in the EU', in: Actualia strafrecht en criminologie, L. Pauwels and G. Vermeulen (ed.), update in de criminologie V, Antwerp-Apeldoorn, Maklu, 2010, 22 p.

8 M. Grapendaal, E. Leeuw and J.M. Nelen, De economie van het drugsbestaan. Criminaliteit als expressie van levensstijl en loopbaan, WODC - Gouda Quint, The Hague, 1991.

9 B. De Ruyver, G. Vermeulen, P. Franck and L. Van Daele, Kansarmoede, druggebruik, criminaliteit, Gent, UGent, 1992, $410 \mathrm{p}$.

10 JLS/2009/JPEN/PR/0028/E4.

11 G. Vermeulen, W. De Bondt and C. Ryckman, Rethinking international cooperation in criminal matters in the EU. Moving beyond actors, bringing logic back, footed in reality, Antwerp-Apeldoorn-Portland, Maklu, 2011 (forthcoming).

12 For the legal instruments mentioned in the below text, see: G. Vermeulen (ed.), Essential Texts on International and European Criminal Law, 6th edition, Antwerp-Apeldoorn, Maklu, 2010, 1370 p. The text itself is mostly a reworked compilation of (translated) excerpts from: G. Vermeulen, W. De Bondt and C. RYCKMAN, Rethinking international cooperation in criminal matters in the EU. Moving beyond actors, bringing logic back, footed in reality, Antwerp-ApeldoornPortland, Maklu, 2011 (forthcoming); G. Vermeulen, W. De Bondt and Y. Van Damme, 'Towards mutual recognition of investigative measures and free movement of evidence', in: Actualia strafrecht en criminologie, L. PAUWELS and G. Vermeulen (ed.), Update in de criminologie V, Gandaius, AntwerpApeldoorn, Maklu, 2010, 21-45; G. Vermeulen, 'Naar wederzijdse erkenning van onderzoeksmaatregelen en vrij verkeer van bewijs in de EU?', Expertise en Recht, 2010, 113-123, as partly (as far as forensic and scientific evidence is concerned) integrated into G. Vermeulen, 'Vrij verkeer van bewijs in de EU?', in: Bewijs in strafzaken. Wetenschappelijke en juridische verkenning van hedendaagse 
aspecten van nationaal en Europees strafrecht m.b.t. bewijs. La preuve en droit pénal. Approche scientifique et juridique de quelques aspects actuels du droit national et européen de la prevue en matière pénale, J.-P. BeAuthier, D. Flore, A. Masset, P.Traest and G. Vermeulen (ed.), Brussels, La Charte, 2011,81-101. Conceptually, it predominantly builds on: G. Vermeulen, 'Samenwerking met strafrechtelijke finaliteit in de EU. De autoriteitenstrijd voorbij, op zoek naar meer coherentie', in: Universalis. Liber Amicorum Cyrille Fijnaut, T. Spapens, M. Groenhuijsen and T. Kooijmans, Antwerp - Cambridge, Intersentia, 2011, 363-384; G. Vermeulen, W. De Bondt and Y. VAN Damme, EU cross-border gathering and use of evidence in criminal matters. Towards mutual recognition of investigative measures and free movement of evidence?, Antwerp-Apeldoorn-Portland, Maklu, 2010, 254 p.; G. Vermeulen (ed.), 'Stockholm richting toekomst, via Brussel. Politie, justitie en strafrecht in de Europese Unie, episode 2010-2014', Panopticon, 2009.2, 1-6; G. Vermeulen, T. Vander Beken, L. Van Puyenbroeck and S. Van Malderen, Availability of law enforcement information in the European Union. Between mutual recognition and equivalent access, Antwerp-Apeldoorn, Maklu, 2005, 110 p.; G. Vermeulen, 'Mutual recognition, harmonisation and fundamental (procedural) rights protection', in: Crime, Rights and the EU. The future of police and judicial cooperation, London, Justice, 2008, 89-104; G. Vermeulen, 'How far can we go in applying the principle of mutual recognition?', in: The future of police and judicial cooperation in the European Union, C. FIJNAUT and J. Ouwerkerk, Leiden, Martinus Nijhoff Publishers, 2010, 241-258; G. Vermeulen and L. VAn Puyenbroeck, 'Approximation and mutual recognition of procedural safeguards of suspects and defendants in criminal proceedings throughout the European Union', in: EU and International Crime Control. Topical Issues, M. Cools, B. De Ruyver, M. Easton, L. Pauwels, P. Ponsaers, G. Vande Walle, T. Vander Beken, F. Vander Laenen, G. Vermeulen and G. Vynckier (ed.), Governance of Security Research Paper Series (GofS), Volume 4, Antwerp-Apeldoorn-Portland, Maklu, 2010, 41-62; G. Vermeulen, 'Het nieuwe Uniestrafrecht: verwezenlijkingen, perspectieven en uitdagingen', in: Van Pionier naar onmisbaar. Over 30 jaar Panopticon, W. Bruggeman, E. De Wree, J. Goethals, P. Ponsaers, P. Van Calster, T. Vander Beken and G. Vermeulen (ed.), Antwerp-Apeldoorn, Maklu, 2009, 635649. Punctually, the text conceptually also draws from: G. Vermeulen, Advisory opinion: JIT and pre-JIT cooperation possibilities in the relationship between The Netherlands and other countries involved in the JIT-initiative(s) initiated under the Netherlands EU Presidency 2004, in particular Belgium and Germany, The Hague, Netherlands EU Presidency (Police), 2004, 32 p. (confidential); C. RIJKEN and G. Vermeulen (ed.), Joint Investigation Teams in the European Union. From Theory to Practice, The Hague, Asser/Cambridge, 2006, 229 p.; G. Vermeulen, T. Vander Beken, E. De Busser and A. Dormaels, Blueprint for an EU criminal records database. Legal, politico-institutional and practical feasibility, AntwerpApeldoorn, Maklu, 2002, 91 p.; P.-E. Schmitz, A. Mennens, R. Vanhecke, W. De Wever, K. Aisola, M. Flammang, A. Boujraf, O. Dubois, G. Vermeulen and L. Van Puyenbroeck, Review of National Criminal Records Systems in the European Union, Bulgaria and Romania with a view to the Development of a Common Format for the Exchange of Information on Criminal Records, Unisys, Brussels, 2006, 204 p.; G. Vermeulen and W. De Bondt, EULOCS. The EU level 
offence classification system: A bench-mark for enhanced internal coherence of the EU's criminal policy, Antwerp-Apeldoorn-Portland, Maklu, 2009, 112 p..

13 HOME/2010/ISEC/PR/068-A3.

14 G. Vermeulen, 'Gewapend bestuur. Kan het bestuur zich wapenen' in: Het strafrechtssysteem in de Laatmoderniteit, T. Balthazar, J. Christiaens, M. Cools, T. Decorte, B. De Ruyver, P. Hebberecht, P. Ponsaers, S. Snacken, P. Traest, T. Vander Beken and G. Vermeulen (ed.), Mechelen, Gandaius - Kluwer, 2004, 169-172. See also: K. Van Heddeghem, T. Vander Beken, G. Vermeulen and B. De RuYver, Gewapend bestuursrecht gescreend, Antwerp-Apeldoorn, Maklu, 2002, $212 \mathrm{p}$.

15 B. De Ruyver, T. Vander Beken and G. Vermeulen, 'The desirability of legally regulating the proactive phase', in: Undercover policing and accountability from an international perspective, M. DEN BoER (ed.), Maastricht, European Institute of Public Administration, 1997, 109-112.

16 See in particular: E. De Busser, Data protection in the EU and EU criminal cooperation. A substantive law approach to the EU internal and transatlantic cooperation in criminal matters between judicial and law enforcement authorities, Antwerp-Apeldoorn-Portland, Maklu, 2009, 104-106; E. DE Busser and G. Vermeulen, 'Towards a coherent EU policy on outgoing data transfers for use in criminal matters? The adequacy requirement and the framework decision on data protection in criminal matters. A transatlantic exercise in adequacy', in: EU and International Crime Control. Topical Issues, M. Cools, B. De RuYver, M. Easton, L. Pauwels, P. Ponsaers, G. Vande Walle, T. Vander Beken, F. Vander Laenen, G. Vermeulen and G. Vynckier (ed.), Governance of Security Research Paper Series (GofS), Volume 4, Antwerp-Apeldoorn-Portland, Maklu, 2010, 95-122; G. Vermeulen, 'Transatlantisch monsterverbond of verstandshuwelijk? Over het verschil tussen oorlog en juridische strijd tegen terreur en de versterkte politie- en justitiesamenwerking tussen EU en VS', Panopticon, 2004, nr. 1, 90-107.

17 ECHR, No 8544/79, Öztürk v. Germany, 21 February 1984.

18 G. Vermeulen and W. De Bondt, EULOCS. The EU level offence classification system: A bench-mark for enhanced internal coherence of the EU's criminal policy, Antwerp-Apeldoorn-Portland, Maklu, 2009, 112 p.

19 G. Vermeulen and Y. Van Damme, Nederlandse afhandeling van Belgische rechtshulpverzoeken, Antwerp-Apeldoorn-Portland, Maklu, 2010, 192 p. (still under embargo)

20 See e.g. G. Vermeulen (ed.), EU standards in witness protection and collaboration with justice, Antwerp-Apeldoorn, Maklu, 2005, 280 p.; S. GLuščIč, G. KLEMENČıč, T. Ljubin, D. Novosel, D. Tripalo and G. Vermeulen, Protecting witnesses of serious crime. Training manual for law enforcement and judiciary, Strasbourg, Council of Europe Publishing, 2006, 373 p. 

The landscape of cross-border evidence gathering in criminal matters in the EU has become blurred. Non-traditional actors, such as administrative authorities and intelligence services, have joined traditional judicial and law enforcement authorities in a domain which used to be looked upon as predominantly judicial cooperation territory. Criminal justice and administrative finalities run the risk of being constantly mixed up. This creates problems in light of the separation of powers, adequate legal and procedural protection in criminal matters and data protection. Gert Vermeulen believes that restoring the balance requires stepping away from traditional authority-based thinking and policy-making. He suggests to embrace 'criminal justice finality' as the key normative marker for EU cross-border intelligence, information and evidence gathering and exchange in criminal matters. The traditional distinction between judicial and police cooperation in criminal matters can no longer be upheld, he concludes. He argues that the distinction is largely artificial, creates confusion and produces inconsistencies, thus hindering the establishment and further development of a coherent EU criminal law policy.

Vermeulen also challenges the envisaged roll-out of the mutual recognition principle in the context of cross-border evidence gathering. He is in particular concerned that it would prompt an inacceptable burden upon criminal justice systems either financially or in terms of operational capacity.

In order to systemically prevent admissibility problems of crossborder evidence in courts throughout the EU, he finally pleas for a free movement regime for evidence, based on common minimum procedural standards according to which it must have been gathered.

Prof. dr. Gert Vermeulen is professor of international and European criminal law at Ghent University, director of the Institute for International Research on Criminal Policy (IRCP) and extraordinary professor of evidence law at Maastricht University.

www.maklu.eu

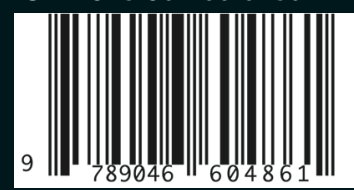

